\title{
Ovine epididymal spermatozoa preservation in liquid state with or without seminal plasma epididimários ovinos
}

\author{
Tácia Gomes Bergstein-Galan ${ }^{1 * 2} \odot$ Romildo Romualdo Weiss ${ }^{1,3}$ \\ Thiago Salvati Rodrigues Barbosa ${ }^{3}{\text { Luiz Ernandes Kozicki }{ }^{4} \odot \text { Sony Dimas Bicudo }}^{5}$
}

\footnotetext{
'Engenharia de Bioprocessos e Biotecnologia, Departamento de Tecnologia, Universidade Federal do Paraná (UFPR), Curitiba, PR, Brasil. E-mail: tacia@alamos.com.br. "Corresponding author. ${ }^{2}$ Central Álamos de Genética, Balsa Nova, PR, Brasil.

${ }^{3}$ Ciência Veterinárias, Departamento de Medicina Veterinária, Universidade Federal do Paraná (UFPR), Curitiba, PR, Brasil. ${ }^{4}$ Estudos em Ciência Animal, Departamento de Medicina Veterinária, Pontifícia Universidade Católica do Paraná (PUCPR), Curitiba, PR, Brasil. ${ }^{5}$ Departamento de Reprodução Animal e Radiologia Veterinária, Faculdade de Medicina Veterinária e Zootecnia (FMVZ), Universidade Estadual Paulista (UNESP), Botucatu, SP, Brasil.
}

ABSTRACT: Preservation and use of spermatozoa that have been recovered after death can extend the use of genetically superior animals. The objective of this study was to evaluate the maximum period for which ovine spermatozoa could be successfully stored in refrigerated dilution medium post-mortem, with or without added seminal plasma. Three samples of spermatozoa collected in an artificial vagina from 10 rams, or from the tails of four epididymes from the same rams at the time of death (G0) and six (G6), twelve (G12), twenty-four (G24) and fortyeight (G48) hours after death were used. After recovery, the spermatozoa were refrigerated at $5^{\circ} \mathrm{C}$ in either control medium (CM) or control medium plus 20\%homologous seminal plasma (SP) and evaluated for 72 hours from the start of refrigeration. The G48 samples had a lower $(P$ $<0.05)$ total motility (TM) and plasma membrane integrity in the hyposmotic test (HOST) than the other groups evaluated at all analyzed times. The TM decreased $(P<0.05)$ after 24 hours of cooling in semen collected in AV, at GO and G24 and after 48 hours of refrigeration in G6 and G12. The TM and HOST integrity and sperm morphology did not differ between samples refrigerated in CM or SP. In conclusion, it is possible to collect epididymal spermatozoa up to 24 hours after death. Sperm viability can be prolonged fora further 48 hours by refrigeration. However, total motility decreases from 24 hours after refrigeration and the supplementation of $20 \%$ seminal plasma to the extender has no effect on spermatozoa longevity.

Key words: refrigeration, epididymis, post mortem.

Preservação em estado líquido, com ou sem plasma seminal, de espermatozóides epididimários ovinos

RESUMO: A recuperação e preservação dos espermatozoides após a morte possibilita maior aproveitamento de animais geneticamente superiores. $O$ objetivo deste trabalho foi avaliar o periodo máximo após a morte do carneiro para que os espermatozoides possam ser refrigerados em meio diluidor com ou sem plasma seminal. Foram utilizadas três amostras de espermatozoides colhidos em vagina artificial $(\mathrm{AV})$ de 10 carneiros ou da cauda de quatro epididimos provenientes dos mesmos carneiros no momento da morte (G0) e seis (G6), doze (G12), vinte e quatro (G24) e quarenta e oito (G48) horas após a morte. Após a recuperação os espermatozoides (em AV ou cauda do epidídimo) foram refrigerados à $5^{\circ} \mathrm{C}$ em dois tratamentos: meio controle (CM) ou meio controle acrescido de 20\% de plasma seminal homólogo (SP) e avaliados até 72 horas após o início da refrigeração. As amostras do G48 apresentaram motilidade total (TM) e integridade de membrana plasmática no teste hiposmótico (HOST) menor $(P<0,05)$ que os outros grupos avaliados em todos os momentos estudados. TM diminuiu $(P<0,05)$ após 24 horas de refrigeração no sêmen colhido em AV, no G0 e G24 e a partir de 48 horas de refrigeração no G6 e G12. A TM, integridade de membrana no HOST e morfologia espermática não diferiram entre as amostras refrigeradas em CM ou SP. Contudo, é possivel refrigerar espermatozoides epididimários até 24 horas post mortem, a refrigeração prolonga a viabilidade espermática até 48 horas após o início da refrigeração. A adição de $20 \%$ de plasma seminal ao meio diluidor não tem efeito sobre a longevidade espermática.

Palavras-chave: refrigeração, epididimo, post mortem.

\section{INTRODUCTION}

Recovery of spermatozoa after the sudden death of valuable genetic specimens or animals of zoological interest extends the potential use of male gametes (VIEIRA et al., 2013). Preservation of spermatozoa recovered after death can prolong their viability. Semen can be preserved in either liquid and frozen states (SALAMON \& MAXWELL, 2000). Few studies have evaluated the viability of ovine 
epididymal spermatozoa after recovery, dilution and refrigeration(TAMAYO-CANUL et al., 2011).

The main advantage of cooling sperm in a liquid phase is that this prevents damage associated with freezing, ensuring greater viability of semen (CRESPILHO et al., 2014). Ovine semen, cooled to $5^{\circ} \mathrm{C}$, can be used for artificial insemination for up to three days after collection, but fertility begins to decline after 24 hours of storage (O'HARA et al., 2010).

The addition of seminal plasma to the extender seems to provide protection for ovine sperm cells, thus maintaining the total motility when semen is refrigerated (MATA-CAMPUZANO et al., 2014) or frozen (DOMÍNGUEZ et al., 2008) and increasing the pregnancy rate in inseminated ewes (LÓPEZ-PÉREZ; PÉREZ-CLARIGET, 2012). Sperm recovered directly from the epididymis has no seminal plasma, necessitating specific handling conditions to minimize deterioration in sperm quality, particularly with regard to motility (BERTOL et al., 2013). The varying reports on the effects of addition of seminal plasma to ram epididymal spermatozoa are contradictory: GRAHAM (1994) reported a positive effect on motility during refrigeration and cryopreservation, in contrast, other authors (DOTT et al., 1979), have reported that; although, seminal plasma initially stimulated motility, it was detrimental to sperm survival after 15 minutes of exposure.

The objectives of this study were: (1) to identify the maximum time after death at which ovine epididymal spermatozoa can be preserved without freezing (2) to evaluate the quality of epididymal spermatozoa preserved in liquid storage at $5^{\circ} \mathrm{C}$ for up to 72 hours after refrigeration, using semen collected in an artificial vagina as a control (3) to evaluate the effect on quality of refrigerated spermatozoa, of supplementation of $20 \%$ of seminal plasma (SP) to the extender.

\section{MATERIALS AND METHODS}

\section{Experiment design}

The project was approved by the Animal Use Ethics Committee of the Agricultural Science Campus of the Universidade Federal do Paraná, protocol number 052/2016. Ten rams, aged between 12 and 24 months, were housed in a semi-intensive system. The rams had access to native grass pasture during the day and were housed in the evening. They were fed with a corn, soybean meal and mineral mix. Water was supplied ad libitum.

Semen was collected with an artificial vagina (AV) using a sheep dummy. The AV was filled with water between 42 and $45^{\circ} \mathrm{C}$. Collections were performed twice a week for two months (January and February) in transition time for breeding season. The following parameters of semen quality were monitored: total motility, progressive motility, morphological defects and membrane functionality (hyposmotic swelling test). When the ten rams reached preset criteria: total motility $>80 \%$, progressive motility $>70 \%$, morphological defects $<15 \%$ and membrane functionality (hyposmotic swelling test) $>90 \%$, two ejaculates from each ram were collected one week apart and the semen was analyzed and refrigerated under the same conditions as would be used for post mortem spermatozoa preservation. Results of these collections comprised the AV group results.

After the second AV collection, rams were slaughtered (March).The scrotum, testes and epididymis were excised using a horizontal section through the spermatic funiculum. An empty styro foam box was used to transport the Complex Scrotum, Testis and Epididymis (CSTE) to the laboratory. In the laboratory CSTE were placed in empty Becker dishes covered with paper towel. The CSTE were kept at room temperature for the period corresponding to the groups of this study.

The CSTE were randomly assigned to one of five groups corresponding to the time they had been kept at room temperature i.e. zero hours (G0), six hours (G6), twelve hours (G12), twenty-four hours (G24) and forty-eight hours (G48). Each group consisted of four CSTE from four different rams.

\section{Spermatozoa recovery post mortem}

The testis and epididymis were removed from the CSTE through a vertical cut in the scrotum. The testes and epididymes were washed with $0.09 \%$ sodium chloride solution warmed to $35^{\circ} \mathrm{C}$. Each epididymis was disconnected from the testicle and sectioned between the tail and the body. Tails of the epididymes were placed in petri dishes warmed to $35^{\circ} \mathrm{C}$. Superficial blood vessels were dissected to minimize blood contamination. Epididymis tail was sectioned and light pressure was applied to eject spermatozoa from the tubules (KAABI et al., 2003). Then the tail of the epididymis was washed with $2 \mathrm{~mL}$ of extender $(200 \mathrm{~mL}$ distilled water, $1.4 \mathrm{~g}$ glycine, $2.97 \mathrm{~g}$ sodium citrate, $3 \mathrm{~g}$ fructose, $0.004 \mathrm{~g}$ amikacin, $15 \mathrm{~mL}$ skimmed milk, $5 \mathrm{~g}$ egg yolk and $4.6 \mathrm{Ml}$ distilled water) warmed to $35^{\circ} \mathrm{C}$.Each epididymis was washed separately in a petri dish. Petri dishes were angled so that the spermatozoa accumulated at one end of the plate. After five minutes the diluted spermatozoa, between 2 and $3 \mathrm{~mL}$,were recovered from the Petri 
dish and the spermatozoa were placed in a conical tube (Falcon BD) (MARTINEZ-PASTOR et al., 2006).

\section{Extenders}

Control media (CM) used as a cooling extender and comprised $75 \mathrm{~mL}$ of mother solution $(200 \mathrm{~mL}$ distillated water, $1.4 \mathrm{~g}$ glycine, $2.97 \mathrm{~g}$ sodium citrate, $3 \mathrm{~g}$ fructose, $0.004 \mathrm{~g}$ amikacin), $15 \mathrm{~mL}$ skimmed milk, $5 \mathrm{~g}$ egg yolk and $4.6 \mathrm{~mL}$ distillated water $(\mathrm{CM})$ (RODELLO et al., 2011). Twenty percent seminal plasma was added to the CM to form the SP medium. Semen collected in the AV from the same ten rams during the sperm standardization period were used to acquire seminal plasma. The seminal plasma was obtained, and SP extender was produced following the methodology of LÓPEZ-PÉREZ \& PÉREZCLARIGET (2012).

\section{Liquid storage and cooling}

According to initial concentration, a spermatozoa aliquot in $2 \mathrm{~mL}$ poly-propylene microtubes (Eppendorf, Hamburg, Germany) was then diluted in $500 \mu \mathrm{L}$ of $\mathrm{CM}$ or SP to reach the final concentration of $400 \times 106$ sperm per mL. Three thermal bags filled with $200 \mathrm{~mL}$ of warmed water at $32^{\circ} \mathrm{C}$ were placed on the top of diluted samples. Samples and thermal bags were placed inside a refrigerator at $5^{\circ} \mathrm{C}$. To facilitate a gradual reduction of temperature to $5^{\circ} \mathrm{C}$, thermal bags were removed from the refrigerator at 35, 50 and 60 minutes after the initiation of cooling process as described by RODELLO et al.(2006). After 0 hours (R0), 6 hours (R6), 12 hours (R12), 24 hours (R24), 48 hours (R48) and 72 hours (R72) from the start of cooling, a $50 \mathrm{uL}$ aliquot suspension was collected from each sample for analysis of total motility (TM), integrity of membranes on hypo-osmotic swelling test (HOST) and morphological pathology of spermatic cells.

\section{Spermatic analyses}

Evaluations of TM were performed under optical microscopy (Coleman, N 107, Brazil). A droplet of spermatozoa diluted to a concentration of $400 \times 106$ sperm per $\mathrm{mL}$ was deposited between the slide and cover slip warmed at $37^{\circ} \mathrm{C}$ and examined at 400x magnification. All the examinations were made by the same person.

To perform the hypo-osmotic swelling test $(\mathrm{HOST}), 10 \mu \mathrm{L}$ of spermatozoa was diluted in $50 \mu \mathrm{L}$ water (HISHINUMA \& SEKINE, 2004) heated to $37^{\circ} \mathrm{C}$. After incubation for 60 minutes in a water bath at $37^{\circ} \mathrm{C}, 10 \mu \mathrm{L}$ of this suspension was placed on a slide and covered with a cover slip and evaluated under an optical microscope at 400x magnification. Two hundred cells per sample were evaluated, sperm with swollen or coiled tails were considered to have functional membranes and were classified as intact.

Sperm morphology was evaluated on slides prepared with scrubbed semen and stained according to the method of CEROVSKY (1976). A differential count of 200 cells per slide was made.

\section{Statistics}

The analyzes were performed in duplicate. The averages of values obtained in each group (AV, G0, G6, G12, G24 and G48 or CM and SP) were used in statistical analysis. Kolmorogov-Smirnov method was used to identify normal distribution and homogeneity of variances. Repeated measures ANOVA test was used to analyze differences between times (time after start of refrigeration). Interaction test followed by ANOVA test were performed to evaluate the relationship between times and media. Tukey multiple comparisons tests were performed on previous tests when $\mathrm{P}$ values were lower than 0.05 . A significance of $5 \%$ was set for all statistical tests. The statistical program Action $\AA$ version 2.6.216.366 was used.

\section{RESULTS}

Table 1 shows TM after 0, 6, 12, 24, 48 and 72 hours of liquid storage at $5^{\circ} \mathrm{C}$. The TM decreased $(\mathrm{P}<0.05)$ after 24 hours of cooling in $\mathrm{AV}, \mathrm{G} 0$ and $\mathrm{G} 24$ when compared to R0. After 48 hours of cooling in G6 and $\mathrm{G} 12$ groups, TMs were decreased $(\mathrm{P}<0.05)$ when compared to R0. In G48 TM decreased gradually but there were no significant differences $(\mathrm{P}>0.05)$ between times.

The $\mathrm{G} 24$ and G48 TM were lower $(\mathrm{P}<0.05)$ than AV up to 24 hours of liquid storage. The TMs of G0 and G6 were lower $(\mathrm{P}<0.05)$ than semen collected with an AV only at times R6 and R12 of liquid storage. At R48 and R72 hours of liquid storage no difference ( $\mathrm{P}>0.05)$ were observed between TM in AV semen and epididymal spermatozoa.

The percentage of intact sperm in HOST was lower $(\mathrm{P}<0.05)$ in $\mathrm{G} 0$ at 6 hours and G48 at R0 and R24 hours after cooling when compared to the AV group (Table 2). There was no difference $(\mathrm{P}>0.05)$ in percentage of acrosomal and tail defects between the groups at any time.

There was no significant difference $(\mathrm{P}=$ 0.6290 ) in total motility (mean \pm standard error) of samples diluted in $\mathrm{CM}$ and SP and refrigerated at $5^{\circ} \mathrm{C}$ for 0 hours (CM: $73.3 \pm 3.5$; SP: $74.2 \pm 3.4)$, 6 hours $(\mathrm{CM}: 63.9 \pm 3.9$, SP: $66.97 \pm 3.7), 12$ hours (CM: 
Table 1 - Mean \pm standard error of percentage of total motility (TM) of sperm collected using an artificial vagina (AV) and collected from epididymides at $0(\mathrm{G} 0), 6(\mathrm{G} 6), 12(\mathrm{G} 12), 24(\mathrm{G} 24)$ and $48(\mathrm{G} 48)$ hours after ovine death at the time of cooling (R0) and 6(R6), 12(R12), 24(R24), 48(R48) and 72(R72) hours after cooling to $5^{\circ} \mathrm{C}$.

\begin{tabular}{|c|c|c|c|c|c|c|}
\hline & R0 & R6 & $\mathrm{R} 12$ & $\mathrm{R} 24$ & $\mathrm{R} 48$ & $\mathrm{R} 72$ \\
\hline AV & $86.4 \pm 1.0^{\mathrm{a}}$ & $86.36 \pm 1.2^{\mathrm{a}}$ & $81.4 \pm 2.2^{\mathrm{ab}}$ & $68.6 \pm 6.3^{b}$ & $38.4 \pm 5.0^{\mathrm{c}}$ & $17.0 \pm 2.6^{\mathrm{c}}$ \\
\hline G0 & $79.0 \pm 4.3^{\mathrm{a}}$ & $66.0 \pm 4.0^{\mathrm{ab}^{*}}$ & $62.0 \pm 2.5^{\mathrm{ab}^{*}}$ & $60.0 \pm 2.5^{b}$ & $44.0 \pm 5.8^{\mathrm{bc}}$ & $17.0 \pm 3.9^{c}$ \\
\hline G6 & $81.3 \pm 3.9^{\mathrm{a}}$ & $62.5 \pm 6.2^{\mathrm{ab}^{*}}$ & $57.5 \pm 5.2^{\mathrm{ab}^{*}}$ & $56.2 \pm 10.3^{\mathrm{ab}}$ & $40.0 \pm 9.2^{\mathrm{bc}}$ & $17.5 \pm 4.9^{\mathrm{c}}$ \\
\hline G12 & $72.5 \pm 1.6^{\mathrm{a}}$ & $62.5 \pm 1.3^{\mathrm{ab}^{*}}$ & $55.7 \pm 6.7^{\mathrm{ab}^{*}}$ & $52.5 \pm 6.2^{\mathrm{abc} *}$ & $38.7 \pm 3.5^{\mathrm{bc}}$ & $18.7 \pm 3.5^{\mathrm{c}}$ \\
\hline G24 & $70.0 \pm 1.9^{\mathrm{a}^{*}}$ & $57.5 \pm 5.3^{\mathrm{ab}^{*}}$ & $52.5 \pm 6.7^{\mathrm{abc} *}$ & $43.7 \pm 4.20^{b c^{*}}$ & $31.2 \pm 3.9^{\mathrm{c}}$ & $15.0 \pm 4.6^{\mathrm{c}}$ \\
\hline G48 & $39.0 \pm 7.7^{\mathrm{a}^{*}}$ & $30.0 \pm 4.7^{\mathrm{a}^{*}}$ & $21.1 \pm 4.0^{\mathrm{a}^{*}}$ & $7.5 \pm 1.1^{\mathrm{a}^{*}}$ & $13.0 \pm 3.3^{\mathrm{a}}$ & $6.0 \pm 3.4^{\mathrm{a}}$ \\
\hline
\end{tabular}

Different letters $(a, b, c)$ in the same row indicate significant difference $(\mathrm{P}<0.05)$ between moment results in same group. Superscripts followed by ${ }^{*}$ indicates value differs $(\mathrm{P}<0.05)$ from AV group (control treatment) at the same time point $($ column).

$56.4 \pm 4.6$, SP: $59.4 \pm 4.1), 24$ hours $(\mathrm{CM}: 52.0 \pm$ 5.2 , SP: $51.2 \pm 5.0), 48$ hours $(\mathrm{CM}: 35.7 \pm 3.8$, SP: $33.9 \pm 3.5)$, and 72 hours (CM: $14.5 \pm 2.1$, SP: 14.5 $\pm 2.3)$.No significant differences between $\mathrm{CM}$ and SP groups were seen for HOST $(\%$ intact $)(\mathrm{P}=0.6893)$, acrosome defects $(\mathrm{P}=0.6666)$ nor tail defects $(\mathrm{P}=$ $0.4714)$. No relationship between time of storage and media were identified in TM $(\mathrm{P}=0.8250)$, HOST $(\%$ intact $)(\mathrm{P}=0.3488)$, acrosome $\operatorname{defect}(\mathrm{P}=0.1699)$ nor tail defect $(\mathrm{P}=0.2667)$.

\section{DISCUSSION}

Tissue degeneration begins soon after death. Degeneration of epididymal tubules starts within 18 hours of death in rats (SONGSASEN et al., 1998). In the present study, sperm viability was lower $(\mathrm{P}<0.05)$ in $\mathrm{G} 48$ than other groups. It is likely that tissue degeneration and epididymal cell autolysis promotes increases in the oxygen reactive species (ROS) in the epididymal environment. Excessive concentration of ROS has been associated with increased lipid peroxidation of the plasma membrane of spermatozoa and decreased sperm viability (JONES; MANN, 1977; SICHERLE et al., 2011). Similar results were found by BERGSTEIN-GALAN et al. (2017) who reported that at 48 hours after death ovine spermatozoa had insufficient viability for cryopreservation. The TM from G24 and G48 differed $(\mathrm{P}<0.05)$ from control treatment $(\mathrm{AV})$ (Table 1); however, only G48 had lower $(\mathrm{P}<0.05)$ plasma membrane integrity when compared to AV. Consequently, the authors suggested that if ovine epididymal spermatozoa are not recovered until 48 hours post mortem they must be used immediately, if epididymes have been kept at room temperature, because they will be unsuitable for liquid storage.

The cooling of sperm in liquid suspension slows metabolism, increases sperm survival and maintain sperm fertility (KANEKO et al., 2009), but the storage time has effects on sperm motility and viability (SALAMON \& MAXWELL, 2000; SARIÖZKAN et al., 2014). BERGSTEIN-GALAN et al. (2016) reported that TM of ovine semen collected in an $\mathrm{AV}$ decreased at 48 hours after the start of refrigeration at $5^{\circ} \mathrm{C}$. However, in the present study, TM of the AV group decreased $(\mathrm{P}<0.05)$ by 24 hours $(68.6 \pm 6.3 \%)$ after the onset of refrigeration when compared to R0 $(86.4 \pm 1.0 \%)$. The length of time over which semen can be stored without a deterioration in quality varies according to the constitution of media (SARIÖZKAN et al., 2012), chilling curve (SALAMON \& MAXWELL, 2000) and sperm concentration of the sample (MATACAMPUZANO et al., 2014). Semen collected with an AV had higher $(\mathrm{P}<0.05)$ TM between 6 and 12 hours of refrigeration compared to epidydimal samples (Table 1). The percentage of intact sperm in HOST was lower $(\mathrm{P}<0.05)$ in $\mathrm{G} 0$ at 6,12 and 24 hours and G48 at 0 and 24 hours after cooling compared to the AV group. It is possible that the absence of tissue debris in ejaculated sperm may have resulted in better preservation of these samples in liquid storage, although the difference did not persist beyond 24 hours of storage.

In this study the dilution of samples in medium containing glycine, egg yolk and milk enabled the maintenance of TM $(\mathrm{P}>0.05)$ for 24 hours of liquid storage in G6 and G12 groups, and for 12 hours in G0 and G24 groups. However, G48 had a lower TM at all times analyzed, and it is likely that by 
Table 2 - Mean \pm standard error of percentage of spermatozoa with plasma membrane integrity in the hyposmotic test (HOST) from sperm collected using an artificial vagina (AV) and collected from epididymides at $0(\mathrm{G} 0), 6(\mathrm{G} 6), 12(\mathrm{G} 12), 24(\mathrm{G} 24)$ and $48(\mathrm{G} 48)$ hours after ovine death at the time of cooling (R0) and 6(R6), 12(R12), 24(R24), 48(R48) and 72(R72) hours after cooling to $5^{\circ} \mathrm{C}$.

\begin{tabular}{lcccccc}
\hline & R0 & R6 & R12 & R24 & R48 \\
AV & $90.4 \pm 1.3^{\mathrm{a}}$ & $87.3 \pm 0.7^{\mathrm{a}}$ & $65.4 \pm 2.9^{\mathrm{b}}$ & $81.9 \pm 2.9^{\mathrm{a}}$ & $65.9 \pm 2.7^{\mathrm{b}}$ & $63.2 \pm 2.1^{\mathrm{b}}$ \\
G0 & $82.0 \pm 0.6^{\mathrm{a}}$ & $72.1 \pm 2.2^{\mathrm{ab}^{*}}$ & $81.2 \pm 1.6^{\mathrm{a}^{*}}$ & $61.0 \pm 1.9^{\mathrm{b}^{*}}$ & $74.0 \pm 1.4^{\mathrm{ab}}$ & $66.5 \pm 3.9^{\mathrm{ab}}$ \\
G6 & $77.1 \pm 2.0^{\mathrm{a}}$ & $73.4 \pm 1.9^{\mathrm{a}}$ & $73.7 \pm 1.4^{\mathrm{a}}$ & $68.4 \pm 3.7^{\mathrm{a}}$ & $66.0 \pm 1.0^{\mathrm{a}}$ & $68.5 \pm 2.5^{\mathrm{a}}$ \\
G12 & $79.1 \pm 5.2^{\mathrm{a}}$ & $79.7 \pm 1.5^{\mathrm{a}}$ & $65.7 \pm 8.7^{\mathrm{a}}$ & $71.2 \pm 3.2^{\mathrm{a}}$ & $69.5 \pm 3.9^{\mathrm{a}}$ & $64.2 \pm 4.1^{\mathrm{a}}$ \\
G24 & $77.4 \pm 1.2^{\mathrm{a}}$ & $73.0 \pm 4.6^{\mathrm{a}}$ & $72.5 \pm 3.7^{\mathrm{a}}$ & $72.5 \pm 4.7^{\mathrm{a}}$ & $71.2 \pm 5.5^{\mathrm{a}}$ & $74.7 \pm 3.5^{\mathrm{a}}$ \\
G48 & $60.0 \pm 8.0^{\mathrm{a}^{*}}$ & $76.0 \pm 1.1^{\mathrm{a}}$ & $64.9 \pm 4.3^{\mathrm{a}}$ & $69.0 \pm 1.4^{\mathrm{a}^{*}}$ & $58.2 \pm 1.6^{\mathrm{a}}$ & $56.4 \pm 3.2^{\mathrm{a}}$ \\
\hline
\end{tabular}

Different letters $(a, b, c)$ in the same row indicate significant difference $(\mathrm{P}<0.05)$ between moment results in same group. Superscripts followed by ${ }^{*}$ indicates value differs $(\mathrm{P}<0.05)$ from AV group (control treatment) at the same time point (column).

48 hours after death spermatozoa are unsuitable for liquid storage. A reduction in motility was noted after 24 hours of refrigeration, but AV, G0, G6, G12 and G24 maintained satisfactory (more than 30\%) TM for up to 48 hours in liquid storage. The findings of this study corroborated those of ABELLA et al. (2015) who reported a gradual decrease in the motility of ovine epididymal spermatozoa cooled to $4^{\circ} \mathrm{C}$ and diluted in extender containing milk and egg yolk with $18 \%$ TM after 72 hours of refrigeration.

Extender supplementation with seminal plasma had no effect on any parameter in any group, or when samples were stored for any time at $5^{\circ} \mathrm{C}$. Results of this study were different from other authors who added seminal plasma to extender for sperm cooling (LÓPEZ-PÉREZ \& PÉREZCLARIGET, 2012; MATA-CAMPUZANO et al., 2014). Many factors and interactions change the effect of additional seminal plasma on ram spermatozoa (LEAHY \& DE GRAAF, 2012). Effectiveness of seminal plasma supplementation in maintaining sperm quality varies according to the season in which the seminal plasma is obtained from rams (LEAHY et al., 2010). Adding seminal plasma collected in summer had no effect on sperm quality (DOMÍNGUEZ et al., 2008). Egg yolk in extenders prevents the destabilization of the plasma membrane of spermatozoa (SALAMON\& MAXWELL, 2000), and it is possible that the egg yolk in the two tested extenders was effective in stabilizing the membranes making addition of seminal plasma unnecessary.

\section{CONCLUSION}

In conclusion, it is possible to preserve ovine epidydimal spermatozoa in a liquid state when epididymes have been exposed to room temperature for 24 hours after death. The dilution of epididymal spermatozoa and maintenance of diluted samples at $5^{\circ} \mathrm{C}$ prolongs the longevity of spermatozoa for up to 48 hours after recovery; however, after 24 hours of refrigeration total motility declines. Supplementation of $20 \%$ of seminal plasma to the cooling extender has no effect on epididymal spermatozoa viability.

\section{ACKNOWLEDGEMENTS}

T.G. Bergstein-Galan was supported by scholarship from Coordenação de Aperfeiçoamento de Pessoal de Nível Superior (CAPES).

\section{DECLARATION OF CONFLICTING} INTERESTS

The authors declare no conflict of interest. The founding sponsors had no role in the design of the study; in the collection, analyses, or interpretation of data; in the writing of the manuscript, and in the decision to publish the results.

\section{REFERENCES}

ABELLA, D. F. et al. Fertility of undiluted ram epididymal spermatozoa stored for several days at $4{ }^{\circ}$ C. Animal, v. 9, n. 2, p. 313-319, 2015. Available from: <https://www.cambridge.org/core/ journals/animal/article/fertility-of-undiluted-ram-epididymalspermatozoa-stored-for-several-days-at-4c/19522274BF0FD1180 27EABB4E03E444A>. doi: 10.1017/S1751731114002109.

BERGSTEIN-GALAN, T. G. et al. Comparação de três métodos de refrigeração do sêmen ovino pelo período de 24 e 48 horas. Archives of Veterinary Science, v. 21, n. 4, p. 66-73, 2016. Available from: <https://revistas.ufpr.br/veterinary/article/ view/45201/32631>. doi: 10.1016/j.theriogenology.2017.04.001.

BERGSTEIN-GALAN, T. G. et al. Quality and fertility of frozen ovine spermatozoa from epididymides stored at room temperature $\left(18-25^{\circ} \mathrm{C}\right)$ for up to $48 \mathrm{~h}$ post mortem. Theriogenology, v. 96, p. $69-75,2017$. Available from: <http://www.sciencedirect.com/ science/article/pii/S0093691X17301516>. 
BERTOL, M. A. F. et al. Viability of bull spermatozoa collected from the epididymis stored at $18-20^{\circ} \mathrm{C}$. Brazilian Archives of Biology and Technology, v. 56, n. 5, p. 777-783, 2013. Available from: $<$ http://www. scielo.br/scielo.php?pid=S1516-89132013000500008\&script $=$ sci abstract>. doi: 10.1590/S1516-89132013000500008.

CEROVSKY, J. A. A new staining procedure for boar spermatozoa. Zivocisna Vyroba, v. 21, p. 351-362, 1976.

CRESPILHO, A. M. et al. Sperm fertility and viability following $48 \mathrm{~h}$ of refrigeration: evaluation of different extenders for the preservation of bull semen in liquid state. Animal reproduction science, v. 146, n. 3-4, p. 126-133, maio 2014. Available from: <http://www. sciencedirect.com/science/article/pii/S0378432014000694>. doi: 10.1016/j.anireprosci.2014.02.020.

DOMÍNGUEZ, M. P. et al. Seasonal variations in the composition of ram seminal plasma and its effect on frozen-thawed ram sperm. Theriogenology, v. 69, n. 5, p. 564-573, 15 mar. 2008. Available from: <http://www.sciencedirect.com/science/article/pii/ S0093691X07006498>. doi: 10.1016/j.theriogenology.2007.11.010.

DOTT, H. M.; HARRISON, R. A; FOSTER, G. C. The maintenance of motility and the surface properties of epididymal spermatozoa from bull, rabbit and ram in homologous seminal and epididymal plasma. Journal of reproduction and fertility, v. 55, p. 113-124, 1979. doi: 10.1530/jrf.0.0550113.

GRAHAM, J. K. Effect of seminal plasma on the motility of epididymal and ejaculated spermatozoa of the ram and bull during the cryopreservation process. Theriogenology, v. 41, n. 5, p. 1151-1162, 1994.

HISHINUMA, M.; SEKINE, J. Separation of canine epididymal spermatozoa by Percoll gradient centrifugation. Theriogenology, v. 61 , n. $2-3$, p. $365-372$, 2004. Available from: <https://www. sciencedirect.com/science/article/pii/S0093691X0300219X $>$. doi: 10.1016/S0093-691X(03)00219-X.

JONES, R.; MANN, T. Damage to ram spermatozoa by peroxidation of endogenous phospholipids. Journal of reproduction and fertility, v. 50, p. 261-268, 1977. doi: 10.1530/jrf.0.0500261.

KAABI, M. et al. Effect of epididymis handling conditions on the quality of ram spermatozoa recovered post-mortem. Theriogenology, v. 60 , p. 1249-1259, 2003. Available from: $<$ https://www.ncbi.nlm.nih.gov/pubmed/14511779>. doi: 10.3923/ ajava.2008.400.408.

KANEKO, T. et al. Fertilization of C57BL/6 mouse sperm collected from cauda epididymides after preservation or transportation at $4^{\circ} \mathrm{C}$ using laser-microdissected oocytes. Cryobiology, v. 59, n. 1, p. 59-62, 2009. Available from: <https://www.ncbi.nlm.nih.gov/ pubmed/19394323>. doi: 10.1016/j.cryobiol.2009.04.006.

LEAHY, T. et al. Seasonal variation in the protective effect of seminal plasma on frozen-thawed ram spermatozoa. Animal Reproduction Science, v. 119, n. 1-2, p. 147-153, maio 2010. Available from: <http://linkinghub.elsevier.com/retrieve/pii/ S0378432009003029>. doi: 10.1111/j.1439-0531.2012.02077.x.

LEAHY, T.; DE GRAAF, S. P. Seminal plasma and its effect on ruminant spermatozoa during processing. Reproduction in Domestic Animals, v. 47, n. SUPPL.4, p. 207-213, 2012. Available from: $<$ https://www.ncbi.nlm.nih.gov/pubmed/22827372>. doi: 10.1016/j. anireprosci.2009.12.010
LÓPEZ-PÉREZ, A.; PÉREZ-CLARIGET, R. Ram seminal plasma improves pregnancy rates in ewes cervically inseminated with ram semen stored at $5{ }^{\circ} \mathrm{C}$ for 24 hours. Theriogenology, v. 77, n. 2, p. 395-399, 15 jan. 2012. Available from: <http://www. sciencedirect.com/science/article/pii/S0093691X11004171>. doi: 10.1016/j.theriogenology.2011.08.013.

MARTINEZ-PASTOR, F. et al. Comparison of two methods for obtaining spermatozoa from the cauda epididymis of Iberian red deer. Theriogenology, v. 65, n. 3, p. 471-485, 2006. Available from: $<$ https://www.ncbi.nlm.nih.gov/pubmed/15996726>. doi: 10.1016/j. theriogenology.2005.05.045.

MATA-CAMPUZANO, M. et al. Refrigerated storage of ram sperm in presence of Trolox and GSH antioxidants: Effect of temperature, extender and storage time. Animal Reproduction Science, v. 151, n. 3-4, p. 137-147, 2014. Available from: <http:// linkinghub.elsevier.com/retrieve/pii/S0378432014003042>. doi: 10.1016/j.anireprosci.2014.10.006.

O'HARA, L. et al. Effect of storage duration, storage temperature, and diluent on the viability and fertility of fresh ram sperm. Theriogenology, v. 73, n. 4, p. 541-549, 1 mar. 2010. Available from: $<$ http://linkinghub.elsevier.com/retrieve/pii/S0093691X09004695>. doi: 10.1016/j.theriogenology.2009.10.009.

RODELLO, L. Validação de sistema automatizado de refrigeração e congelação de sêmen ovino. [s.1.] Universidade Estadual Paulista Faculdade de Medicina Veterinária e Zootecnia, 2006.

RODELLO, L. et al. Implicações da redução na concentração de gema de ovo no meio glicina-gema-leite sobre a cinética, morfologia e integridade de membranas espermáticas em sêmen ovino criopreservado. Veterinária e Zootecnia, v. 18, n. 2, p. 239-248, 2011. Available from: <https://www.bvs-vet.org. br/vetindex/periodicos/veterinaria-e-zootecnia/18-(2011)-2/ implicacoes-da-reducao-na-concentracao-de-gema-de-ovono-meio-glicina-/>.

SALAMON, S.; MAXWELL, W. M. C. Storage of ram semen. Animal Reproduction Science, v. 62, n. 1-3, p. 77-111, 2000. doi: 10.1016/S0378-4320(00)00155-X.

SARIÖZKAN, S. et al. The effects of different sugars on motility, morphology and DNA damage during the liquid storage of rat epididymal sperm at $4^{\circ} \mathrm{C}$. Cryobiology, v. 65, n. 2, p. 93-97, 2012. Available from: <https://www.ncbi.nlm.nih.gov/ pubmed/22634115>. doi: 10.1016/j.cryobiol.2012.05.007.

SARIÖZKAN, S. et al. In vitro effects of 1-carnitine and glutamine on motility, acrosomal abnormality, and plasma membrane integrity of rabbit sperm during liquid-storage. Cryobiology, v. 68, n. 3, p. 349-353, 2014. Available from: <https://www.ncbi.nlm. nih.gov/pubmed/24759298>. doi: 10.1016/j.cryobiol.2014.04.006.

SICHERLE, C. C. et al. Lipid peroxidation and generation of hydrogen peroxide in frozen-thawed ram semen supplemented with catalase or Trolox. Small Ruminant Research, v. 95, n. 2-3, p. 144-149, 2011. Available from: <http://dx.doi. org/10.1016/j.smallrumres.2010.10.011>. doi: 10.1016/j. smallrumres.2010.10.011.

SONGSASEN, N.; TONG, J.; LEIBO, S. Birth of live mice derived by in vitro fertilization with spermatozoa retrieved up to twenty-four hours after death. J Exp Zool, v. 280, n. 2, p. 189196, 1998. Available from: <https://onlinelibrary.wiley.com/doi/ 
abs/10.1002/\%28SICI\%291097-010X\%2819980201\%29280\%3A2

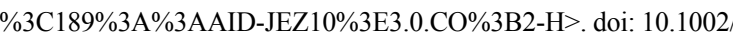
(SICI)1097-010X(19980201)280:2<189::AID-JEZ10>3.0.CO;2-H.

TAMAYO-CANUL, J. et al. Undiluted or extended storage of ram epididymal spermatozoa as alternatives to refrigerating the whole epididymes. Animal reproduction science, $v$ 126, n. $1-2$, p. $76-82$, 2011. Available from: <http://www.
sciencedirect.com/science/article/pii/S0378432011001175>. doi: 10.1016/j.anireprosci.2011.04.011.

VIEIRA, L. A. et al. Equine spermatozoa stored in the epididymis for up to $96 \mathrm{~h}$ at $4^{\circ} \mathrm{C}$ can be successfully cryopreserved and maintain their fertilization capacity. Animal Reproduction Science, v. 136, n. 4,p. 280 288, 2013. Available from: <https://www.healthadvance.com/article/ S0378-4320(12)00342-9/pdf>. doi: 10.1016/j.anireprosci.2012.10.027. 